\title{
The Role of Long-Term Orientation and Service Recovery on the Relationships between Trust, Bonding, Customer Satisfaction and Customer Loyalty: The Case of Nigerian Retail Banks
}

\author{
Muhammad Mujtaba Abubakar ${ }^{1}$, Sany Sanuri Mohd Mokhtar ${ }^{2}$ \& Aliyu Olayemi Abdullattef ${ }^{3}$ \\ ${ }^{1}$ Othman Yeop Abdullah Graduate School of Business, Universiti Utara Malaysia, Malaysia \\ ${ }^{2}$ Quality Management Institute, Universiti Utara Malaysia, Malaysia \\ ${ }^{3}$ College of Business, University Utara Malaysia, Malaysia \\ Correspondence: Muhammad Mujtaba Abubakar, NO 47 2d Sisaran, UUM, Sintok, Kedah, Malaysia. Tel: \\ 60-16-404-8056; 2-3480-6597-4652. E-mail: muhdmabu@gmail.com
}

Received: September 16, 2013 Accepted: November 4, $2013 \quad$ Online Published: December 29, 2013

doi:10.5539/ass.v10n2p209 URL: http://dx.doi.org/10.5539/ass.v10n2p209

\begin{abstract}
In spite of consolidation of Nigerian retail banks, the industry is still embattled by customer complaints, lost of customer confidence and loyalty erosion. Extant literature has amply reported the associations between relational dynamics of trust, bonding, customer satisfaction and customer loyalty. However, these reports are contradictory and thus, inconclusive. Meanwhile, literature has argued extensively on the influence of cultural values on customer decision making and buying behaviour. Yet, very little is known of the interaction effect of long-term orientation on the link between trust, bonding and customer satisfaction in retail banking sector. Similarly, while several studies have documented the significant effect of customer complaints on customer loyalty, there is no noticeable research evidence on the intervening effect of service recovery on the relationship between the independent and the dependent variables. To fill these gaps, this conceptual paper is written.
\end{abstract}

Keywords: banking industry, customer complaints, customer loyalty, customer satisfaction, long-term orientation, relationship marketing, service recovery

\section{Introduction}

In the last three decades, service marketing scholars and researchers have made concerted efforts to find a viable solution to the marketing challenges posed by stiff competition, technological advancement and cultural diversity, and have identified relationship marketing (RM) as the most strategic approach to the issues (Berry, 1995; Gronroos, 1990b; Gummeson \& Gronroos, 2012; Morgan \& Hunt, 1994). The notion of RM hinges on classical social exchange theory (Coelho \& Henseler, 2012; Hunt, Arnett, \& Madhavaram, 2006; Morgan \& Hunt, 1994). The basic assumption of Social exchange theory is that parties voluntarily enter and maintain relationships on the expectation that such relationships will pay back both economically and socially (Blau, 1960; Thibaut \& Kelley, 1959). RM is defined as all marketing activities directed towards establishing, developing and maintaining successful relational exchanges (Morgan \& Hunt, 1994).

Social exchange and RM theories emphasize building and maintaining long-term relationship between sellers and buyers for sustainable competitive advantage and sustainable value added products in favour of the firm and its customers respectively (Gronroos, 1990a). The key outcome of RM is customer loyalty with its attendant efficiency and profitability enhancements (Gronroos, 1994; Gummeson, 1994). Due to the anecdotal and empirical evidence of the strategic role of marketing in banking, the global banking community have embraced marketing tools and techniques such as product positioning in Australia (Kaynak \& Whiteley, 1999), market segmentation in US (Kaynak \& Harcar, 2004), branding in UK (Papasolomou \& Vrontis, 2006) and deposits security in Germany (Hoffmann \& Binbrich, 2012) among others.

In response to global trends, the Nigerian authorities in 2004, introduced banks consolidation (Soludo, 2006). The initiative has succeeded in raising the total assets of the banks from $\$ 28.24$ billion to $\$ 49.88$ billion in the first year alone (Ernest, 2012) and by 2011 , the assets figure stood at $\$ 117$ billion and is projected to reach $\$ 168$ billion by the year 2015 (KPMG, 2013). Taken together, consolidation has improved the running efficiency of 
Nigerian retail banks through mergers and acquisitions (Ernest, 2012). However, consumer related issues of the industry are far from been resolved (Ezioha, 2007; KPMG, 2012) which suggest the application of RM tactics (Kantsperger \& Kunz, 2010). Industry reports and empirical research findings describe the Nigerian banking landscape as undergoing shift in consumer confidence and trust with the attendant loyalty erosion (Adebayo, David, \& Samuel, 2012; KPMG, 2012; Sanusi, 2012) occasioned by customer dissatisfaction, frustrations and unresolved conflicts (KPMG, 2012, 2013; Ogbadu \& Usman, 2012; Ogunnaike \& Olalekan, 2010). Against this backdrop, this paper suggests that the consumer related issues of the Nigerian banks could be traced to the antecedents of individual customer value orientation and service failure recovery.

Several studies have reported significant relationship between RM dynamics of trust (e.g., Armstrong \& Seng, 2000; Caceres \& Paparoidamis, 2007; Kantsperger \& Kunz, 2010; Morgan \& Hunt, 1994), bonding (e.g., Geddie, Defranco, \& Geddie, 2005; Hau \& Ngo, 2012; Narteh, Agbemabiese, Kodua, \& Braimah, 2013) and customer satisfaction and loyalty. However, the findings of these studies are mixed and thus, inconclusive. Similarly, many studies have reported significant effect of customer complaints (e.g., Awwad, 2011; Fornell, Johnson, Anderson, Cha, \& Bryant, 1996; Zeithaml, Berry, \& Parasuraman, 1996) and service recovery (e.g., Boshoff, 1999; Boshoff \& Leong, 1998; Dewitt, Nguyen, \& Marshall, 2007; Kitapci \& Dortyol, 2009) on customer loyalty. Yet, service recovery application is not quite understood in the banking sector (Kumunda \& Osarenkhoe, 2012). Furthermore, our literature review reveals a near absence of research on the intervening role of service recovery on the relationship between customer complaints and customer loyalty in retail banking. To the best of the researchers' knowledge, no previous study has either conceptually or empirically address the suggested moderation and mediation.

\section{Literature Review}

\subsection{Customer Loyalty}

Customer loyalty, defined as strongly held commitment to a product or brand in a manner that the customer desires to patronize and buy the product consistently in the future without resort to switching factors and marketing appeals (Oliver, 1997, 1999). The author argues that the concept consists of two main components, namely behavioural and attitudinal and that loyalty has four stages (Oliver, 1997). Attitudinal loyalty in particular grows through three phases (i.e cognitive, affective and conative) and that action or behavioural loyalty develops after the passage of the three stages (Oliver, 1997). Oliver (1999) described this action as the dream of the business. However, Evanschitzky \& Wunderlich (2006) noted that action does not automatically leads to buying since not all intentions are translated into action. Thus, Beerli, Martin \& Quintana (2004) distinguished between true brand loyalty and loyalty based on inertia. True brand loyalty constitutes the target of retail bank customer relations.

This paper uses six items adapted from four sources (see table 1.0) to measure customer loyalty, using 5 points Likert-type scales anchored on $1=$ strongly disagree and $5=$ strongly agree.

Table 1. Customer loyalty measurement items and sources

\begin{tabular}{ll}
\hline Items & Sources \\
\hline I conduct all my banking affairs with my bank & \\
I never seriously considered changing bank & (Beerli et al., 2002; \\
I would recommend my bank to friends and relatives & Caceres et al., 2007; \\
I prefer to pay my bank higher prices than leave for a competitor & $\begin{array}{l}\text { Ehigie, 2006; Zeithaml } \\
\text { I like to say positive things about my bank to other people }\end{array}$ \\
I will consider my bank as my first choice in future & \\
\hline
\end{tabular}

In the retail banking industry, the tenure of the relationship between banks and their customers is naturally long (Leverin \& Liljander, 2006; Santonen, 2007). The practice in the banking industry and other financial houses has been a deliberate and calculated approach to establishing long-term relationship consistent with efficiency building and long-run profitability even though researchers do not agree on the rationale for such tendency (Hamidizadeh, Jazani, Hajikarami, \& Ebrahimi, 2011). Long-term loyalty is the focus of this research because it is better for retail banks in Nigeria and elsewhere to nurture enduring relationships with their customers particularly given the stiff competition that characterized the banking landscape (Ehigie, 2006). 


\subsection{Trust}

It has been argued that effective services marketing depends on the management of trust because the customer typically must buy a service before experiencing it (Berry \& Parasuraman, 1991) and this is particularly true in banking arena (Kantsperger \& Kunz, 2010). Trust is conceptualized to exist when one party has confidence in the reliability and integrity of an exchange partner (Morgan \& Hunt, 1994). This paper measures trust using six items adapted from four sources (see table 2.0) using five point Likert scales anchored by $1=$ strongly disagree and 5 strongly agree.

Table 2. Trust measurement items and sources

\begin{tabular}{ll}
\hline Items & Sources \\
\hline My bank is trustworthy & \\
I have confidence in my bank & (Alvarez et al., 2011; \\
My bank is concerned with the security of my transactions & Chattananon \& Trimetsoontorn, \\
My bank is consistent in providing quality services & 2009; Morgan \& Hunt, 1994; \\
My bank's promises are reliable & Ndubisi \& Wah, 2005). \\
My bank employees show respect to customers & \\
\hline
\end{tabular}

Past studies reveal significant relationship between trust and customer loyalty (e.g., Casielles, Alvarez, \& Martin, 2013; Chattananon \& Trimetsoontorn, 2009; Kantsperger \& Kunz, 2010; Kiyani, Niazi, Rizvi, \& Khan, 2012; Morgan \& Hunt, 1994). For example, Morgan and Hunt (1994) investigated the strategic influence of trust and commitment on the success of RM in the context of US tire dealers and retailers industry and found that trust strongly predict customer loyalty. This finding was supported by Claycomb and Martin (2001) who discovered that 80 per cent of American consumers consider trust as the major factor in deciding to go into relationships with marketers.

In the same vein, trust was found to predict customer satisfaction and loyalty in the context of advertising agencies of France (Caceres \& Paparoidamis, 2007), banking sector of Malaysia (Ndubisi, Wah, \& Ndubisi, 2007), banking sector of Germany (Kantsperger \& Kunz, 2010), Islamic banks in Pakistan (Hassan, Ahmed, Riaz, \& Maqbool, 2012) and telecommunication industry of Taiwan (Liu, Guo, \& Lee, 2011). In addition, the role of trust in the successful execution of RM strategy in the context of retail travel agencies of Spain was examined by Casielles et al. (2005). The findings of the study suggest that trust has a positive effect on customer loyalty and the success of RM in general. In the light of the preceding, this paper hypothesizes as follows:

H1 Trust is significantly related to customer loyalty

$\mathrm{H} 2$ Trust is significantly related to customer satisfaction

\subsection{Bonding}

Building viable bonds, defined as the development of emotional, psychological, economic or physical attachments of two parties acting in a unified manner towards a common destination (Narteh et al., 2013) is one of the primary objectives and success factors of RM (Lambe et al., 2001; Sin, Tse, Yau, Chow, Lee, \& Lu, 2005b). In this paper, bonding is measured by four items adapted from two sources (see table 3.0), using five points Likert-type scales anchored by $1=$ strongly disagree and $5=$ strongly agree.

Table 3. Bonding measurement items and sources

\begin{tabular}{ll}
\hline Items & Sources \\
\hline My bank and I rely on each other & (Chattananon \& \\
My bank and I work in close cooperation & Trimetsoontorn, 2009; \\
My bank and I are in constant touch with each other & Hau \& Ngo, 2012) \\
My bank and I tried hard to establish long relationship & \\
\hline
\end{tabular}


Previous relational studies have shown significant relationship between bonding, customer satisfaction and loyalty (e.g., Claycomb \& Martin, 2001; Geddie et al., 2005; Narteh et al., 2013; Sin et al., 2005b). For example, to investigate the correlations among relational bonds, customer value and customer loyalty, a study involving 613 customers of different segments was conducted in the retail banking industry of Taiwan by Chiu, Hsieh, Li \& Lee (2005). The findings reveal that financial, social and structural bonds predict customer loyalty of the different customer groups. In a related study, Robinson, Abbott and Shoemaker (2005) analyzed the role of emotional bonds in the context of fast-service restaurants in US. The results of the study show that business name, logo, aroma and light could be used by restaurants to create emotional bonds in the minds of their customers which will make them satisfied and loyal to the business.

In a related work, Chattananon and Trimetsoontorn (2009) explored the effect of bonding among other RM dynamics in Thailand through a survey of 166 sales persons and 15 sales managers. The authors conceptualized RM from the perspective of supplier-customer tie as creation and maintenance of relationship between two parties. The findings of the study reveal that bonding, rather than trust, has greater influence on customer loyalty. A similar result was obtained by Narteh et al. (2013) in a study involving 300 customers in the context of luxury and 5-star hotels in Ghana. Accordingly, we hypothesize as follows:

H3 Bonding is significantly related to customer loyalty

$\mathrm{H} 4$ Bonding is significantly related to customer satisfaction

\subsection{Customer Satisfaction}

Previous studies debated extensively on the concept of customer satisfaction without reaching consensus (Churchill \& Suprenant, 1982). Nevertheless, all customer satisfaction (CS) definitions agree that the concept implies the presence of the customer desire to attain fulfilment as a necessary condition (Molina, Martin-Consuegra, \& Esteban, 2007).

Accordingly, Oliver (1980) construed satisfaction as evaluation of the perceived mismatch between prior expectations and the actual performance of the product. He also referred to it as pleasurable fulfilment (Oliver, 1999). Impliedly, satisfaction is the consumer's judgement that consumption gives results against a standard of pleasure versus displeasure (Ceceres \& Paparoidamis, 2007; Zeithaml et al., 1996). This paper uses six items drawn from four sources (see table 4.0) to measure customer satisfaction, using five points Likert-type scale anchored on $1=$ strongly disagree and $5=$ strongly agree.

Table 4. Customer satisfaction measurement items and sources

\begin{tabular}{ll}
\hline Items & Sources \\
\hline I am satisfied with the services I receive from my bank & \\
I believe my bank treats me fairly & (Armstrong \& Seng, 2000; \\
My bank services meet my expectations & Bennet \& Rundle-Thiele, \\
I am proud of my relationship with my bank & 2004; Hau \& Ngo, 2012; \\
My experiences with my bank have always been good & Liverin \& Liljander, 2006) \\
I am completely happy with my bank & \\
\hline
\end{tabular}

Past studies have documented the impact of customer satisfaction on customer loyalty and customer complaints (e.g., Armsrong \& Seng, 2000; Beerli, Martin, \& Quintana, 2004; Bennet \& Rundle-Thiele, 2004; Binninger, 2008; Bowen \& Chen, 2000; Ehigie, 2006; Fornell et al., 1996; Johnson, Gustafsson, Anderassen, Lervic, \& Cha, 2001; Riel, Liljander, Semeija, \& Polsa, 2011). For example, Hallowell (1996) discovered that customer satisfaction accounts for 37 percent of the variation in customer loyalty in the US, while in Singapore, customer satisfaction explains 74 percent of customer repurchase intention (Armstrong \& Seng, 2000). Similarly, in Belgium, Netherlands and Finland, a study has revealed that car dealership loyalty to main supplier is a function of satisfaction and trust (Riel et al., 2011). In the same vein, the influence of customer satisfaction on bank customer loyalty in Nigerian retail banks was assessed by Ehigie (2006). He discovered that customer loyalty could be improved significantly by implementing strategies that enhance customer satisfaction.

Also, the mediation effect of customer satisfaction on the association between RM dynamics of trust, bonding and customer loyalty was documented (e.g., Ball, Coelho, \& Vilares, 2006; Caceres \& Paparoidamis, 2007; 
Coelho \& Henseler, 2012; Kiyani, Niazi, Rizvi, \& Khan, 2012; Naoui \& Zaiem, 2010). For instance, in the banking sector of Portugal, customer satisfaction was found to mediate the impact of service personalization on customer loyalty (Ball, Coelho, \& Vilares, 2006). Similarly, it is revealed in Coelho and Henseler (2012) that customer satisfaction intervened on the relationship between personalization and bank customer loyalty in a Western European country. Furthermore, most customer satisfaction surveys (e.g., Awwad, 2011; Fornell et al., 1996; Johnson, Gustafsson, Andeasson, Lervic, \& Cha, 2001) have reported the mediation effect of customer satisfaction on the link between perceived quality, perceived value and customer loyalty. They have also validated the significant association between customer satisfaction and customer complaints. That is, while satisfied customers tend to be loyal, dissatisfied customers are prone to complaints (Awwad, 2011; Fornell et al., 1996; Zeithaml, Berry, \& Parasuraman, 1996). Hence, we put forward the following hypotheses:

H5 Customer satisfaction is significantly related to customer loyalty

H6 Customer satisfaction is significantly related to customer complaints

H7 Customer satisfaction mediates the relationship between trust and customer loyalty

H8 Customer satisfaction mediates the relationship between bonding and customer loyalty

\subsection{Possible Moderation Effect of Long-Term Orientation}

Culture, defined as pattern of assumptions, values and beliefs whose shared meaning is acquired by members of a community (Hofstede, 1980) is believed to refine an individual's mind from social environment in which he/she is brought up and to impact his/her perception and attitudes (Ezik \& Au, 2010; Fayolle, Basso, \& Bouchard, 2010; Frost, Goode, \& Hart, 2010; Hofstede, 1980, 1991). In his seminal work, Hofstede (1980) identified what he called national culture to belong to four categories, namely individualism/collectivism, power distance, uncertainty avoidance and masculinity/femininity (Gelfand, Leslie, \& Fehr, 2008; Hui, Ho, \& Wan, 2011; Lai, He, \& Zhou, 2013; Mende, Bolton, \& Bitner, 2013). Later in 1991, Hofstede introduced the fifth category of culture, long-term orientation (Fang, 2003).

Literature has shown that long-term orientation is the least examined Hofstede's culture dimension, perhaps because it is the most misunderstood perspective (Newman \& Nollen, 1996) or because of its Confucian origin (Fang, 2003). Nonetheless, it is the most relevant to relational dynamics (Hofstede, 1983). Scholars have contended that trust and bonding are promoted by long-term orientation through emphasis on social sanctions (Coelho \& Henseler, 2012; Hofstede, 1983). In effect, a customer who shares long-term orientation norms and values is more likely to choose long-term relationship with a bank and has greater tendency towards savings and investment than a customer who shares short-term orientation culture (Hofstede, 1991; Kantsperger \& Kunz, 2010; Narteh et al., 2013; Patterson et al., 2006).

Thus, in this paper long-term orientation is operationalized. Accordingly, five items adapted from a single source (see table 5.0) are used to measure long-term orientation on five point Likert-type scales, anchored on $1=$ strongly disagree and $5=$ strongly agree.

Table 5. Long-term orientation measurement items and sources

\begin{tabular}{ll}
\hline Items & Sources \\
\hline I value careful management of money (thrift) & \\
I remain resolute on my plan in spite of challenges (persistence) & (Kueh \& \\
I believe in personal steadiness and stability & Voon, \\
I cherish Long term planning & 2007 ) \\
I value working hard for success in future & \\
\hline
\end{tabular}

Several studies have reported the influence of culture on customer perception and evaluation of service encounters, satisfaction and behavioural loyalty. For example, examining the effect of cultural diversity on service evaluation, Winsted (1997) discovered that satisfaction with service encounters was higher in US than in Japan. Similarly, in the contexts of Australia and Thailand, Patterson, Cowley \& Prasongsukan (2006) discovered that cultural values of individual power distance, uncertainty avoidance and collectivism interact with a company's service recovery to determine customer perception of justice. In the same vein, uncertainty avoidance and long-term orientation were found to influence service quality expectations in full service restaurants of 
Malaysia by Kueh and Voon (2007). Besides, insignificant relationships were found by past studies between relational dynamics, such as trust, bonding and customer satisfaction (e.g., Hau \& Ngo, 2012; Molina, Martin-Consuegra, \& Esteben, 2007). From the preceding literature, a potential antecedent or moderating value orientation is essentially missing, in previous studies, as argued by John, John \& Baker (2011). Thus, this paper hypothesizes as follows:

H9 Long-term orientation moderates the relationship between trust and customer satisfaction

H10 Long-term orientation moderates the relationship between bonding and customer satisfaction

\subsection{Customer Complaints}

Customer complaints have been construed as disputes or conflicts between customers and the service providers (Singh, 1998). In this paper, customer complaints is measured using four items adapted from three sources (see table 6.0), using five points Likert-type scales anchored by $1=$ strongly disagree and 5-strongly agree.

Table 6. Customer complaints measurement items and sources

\begin{tabular}{ll}
\hline Items & Sources \\
\hline If I experience a problem with my bank, I inform other customers & (Fornell et al., \\
If I experience a problem with my bank, I complain to my bank employees & $1996 ;$ Santanon, \\
If I experience a problem with my bank, I complain to external body & $2007 ;$ Zeithaml et \\
If I experience a problem with my bank, I simply switch to another bank & al., 1996) \\
\hline
\end{tabular}

The significant effect of customer complaints on customer loyalty is well established in literature (e.g., Awwad, 2011; Fornell et al., 1996; Gustafsson, Anderasson, Levic, \& Cha, 2001; Kitapci \& Detryol, 2009; Lobato-Callers, Rivera, Serrato, Gomez, \& Carvantes, 2013; Ryzin, Muzzio, Immerwahr, Gulick, \& Martinez, 2004; Singh, 1998; Zeithaml et al., 1996).

Extant literature posits that satisfied customers can create additional buyers for the business through positive words-of-mouth (WOM) and referrals (Awwad, 2011), dissatisfied customers may react differently such as switching, negative WOM or complain to the firm (Fornell et al., 1996), Thus, satisfied customers have tendency of becoming loyal (Awwad, 2011) and the dissatisfied customers tend to complain (Zeithaml et al., 1996) and if satisfied with Complain handling (i.e. service recovery), their loyalty is reinforced (Dewitt, Nguyen, \& Marshall, 2007; Kitapci \& Dortyol, 2009). In the light of the above, the following hypotheses are made:

H11 Customer complaint is significantly related to customer loyalty

H12 Customer complaint is significantly related to service recovery

H13 Customer complaints mediates the relationship between customer satisfaction and customer loyalty

\subsection{Service Recovery}

Service recovery is conceptualized as the extent to which a customer is satisfied with a company's transaction specific service recovery performance after service failure has occurred (Boshoff, 1999). To measure the concept, this paper drives four items from a single source (see table 7.0), using five point Likert-type scales anchored by $1=$ strongly disagree and 5= strongly agree. Notably, all measures used in this paper have previously achieved Cronbach's alphas consistent with Nunnally (1978).

Table 7. Service recovery measurement items and sources

\begin{tabular}{ll}
\hline Items & Sources \\
\hline I am satisfied with my bank's response to service failure recovery & \\
My bank's service recovery quality exceeds my expectation & Webster and Sundaram \\
My bank's service recovery quality is high & $(1998)$ \\
My bank's service recovery gives me pleasant feelings & \\
\hline
\end{tabular}


In spite of the ample empirical evidence of the role of satisfaction in predicting customer loyalty (e.g., Armstrong \& Seng, 2000; Bowen \& Chen, 2000; Ehigie, 2006; Kantsperger \& Kunz, 2010), there are equally literature evidence showing otherwise (Gurbuz, 2008). Many bank customers, for instance, who are satisfied, are not loyal at the same time (Ehigie, 2006; Leverin \& Liljander, 2006). A possible explanation could be that the customers' complaints are ignored or customers are not satisfied with complaint handling (Fornell et al., 1996). Further, the impact of service recovery on customer loyalty has been reported in several studies (e.g., Boshoff, 1999; Dewitt et al., 2007; Kitapci \& Dortyol, 2009; McCollugh et al., 2000; Orsingher, Valentine, \& Agnes, 2010; Vaerenbergh et al., 2012). However, service recovery is not yet understood in retail banking (Kumunda \& Osarenkhoe, 2012; Palmatier, Javis, Bechkoff, \& Kardes, 2009) may be because the concept started receiving serious research attention only in 2000 (MacCough, Berry, \& Yavad, 2000). From the above literature review, it is evident that the mechanism or process by which customer complaints predict customer loyalty is explained by service recovery (Boshoff, 1999). Put differently, customer complaints predict customer loyalty through the intervening effect of service recovery (Boshoff \& Leong, 1998). Accordingly, the paper suggests the following hypotheses:

H14 Service recovery is significantly related to customer loyalty

H15 Service recovery mediates the relationship between customer complaints and customer loyalty

\section{Proposed Research Framework}

On the basis of the above literature review and discussions, this paper arrives at the research framework depicted on figure 1.0 below, demonstrating that relational dynamics of trust and bonding lead directly to customer loyalty in retail banks (Berry \& Parasuraman, 1996; Gummeson \& Gronroos, 2012; Morgan \& Hunt, 1994) as well as indirectly via customer satisfaction (Armstrong \& Seng, 2000; Coelho \& Henseler, 2012; Kantsperger \& Kunz, 2010). However, it is also documented that relational dynamics like trust and bonding are incapable of producing the desired customer satisfaction (Hau \& Ngo, 2012; Molina et al., 2007) and customer loyalty (Liverin \& Liljander, 2006; Oliver, 1997). Thus, whether or not trust and bonding are sufficient to warrant bank customer satisfaction and subsequent loyalty depends on individual customer value orientation. In effect, the research framework suggests that long-term orientation culture moderates the relationship between trust, bonding and customer satisfaction. The framework also demonstrates the intervening effect of service recovery on the relationship between customer complaints and customer loyalty, meaning that in retail banking, the impact of complaining behaviour on customer loyalty is conceptualized and explained by service recovery.

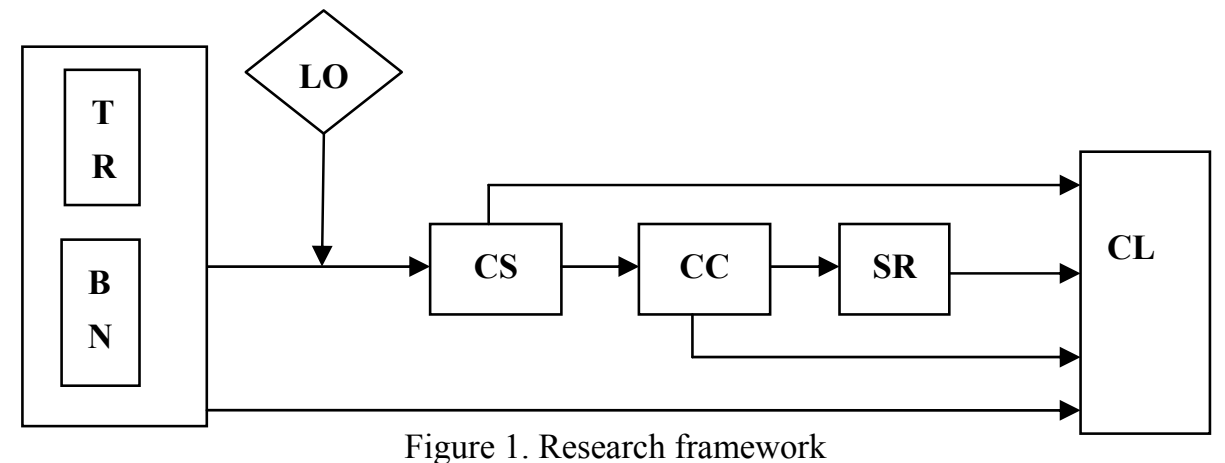

$\mathrm{TR}=$ trust, $\mathrm{BN}=$ bonding, $\mathrm{LO}=$ long-term orientation, $\mathrm{CS}=$ customer satisfaction, $\mathrm{CC}=$ customer complaints, $\mathrm{SR}=$ service recovery, $\mathrm{CL}=$ customer loyalty.

\section{Conclusion, Limitation and Direction for Further Studies}

An overview of this conceptual paper revels that in spite of the several studies on the effect of relational dynamics of trust (e.g., Caceres \& Paparoidamis, 2007; Kantsperger \& Kunz, 2010; Ndubisi et al., 2007; Liu et al., 2011) and bonding (e.g., Hau \& Ngo, 2012; Narteh et al., 2013; Robinson et al., 2005) on customer satisfaction and loyalty, very little is known of the suggested contingent role of long-term orientation culture. In addition, although ample studies have documented the significant impact of customer complaints on customer loyalty (e.g., Dewitt et al., 2007; Fornell et al., 1996; Kitapci \& Dortyol, 2009; Zeithaml et al., 1996), the mechanism and process by which the independent variable impact the dependent variable is neither modelled nor validated by previous studies. 
Therefore, this conceptual paper contributes to theory in two folds. First, it models the interaction effect of long-term orientation culture of the individual customer on the associations between trust, bonding and customer satisfaction, suggesting that the effect of RM on customer satisfaction depends on the value orientation of the individual customer. Second, the paper conceptualizes and explains how customer complaints translate into customer loyalty (Boshoff \& Leong, 1998). Managerially, the conclusions from this paper may assist policy makers and bank managers to formulate strategies that integrate customer value orientation towards enhancing customer satisfaction and loyalty and employ service recovery approach that help mitigates the effects of customer dissatisfaction and service failure.

However, the conceptual nature of this work is its major limitation. Hence, the authors will empirically validate the proposed model subsequently. Future studies may examine the moderating role of masculinity and femininity on the link between trust, bonding and customer satisfaction.

\section{References}

Alvarez, L. S., Casielles, R. V., \& Martin, A. D. (2011). Analysis of the role of complaint management in the context of relationship marketing. Journal of Marketing Management, 27, 143-164. http://dx.doi.org/10.1080/02672571003719088

Armstrong, R. W., \& Seng, T. B. (2000). Corporate customer satisfaction in the banking industry of Singapore. International Journal of Bank Marketing, 18(3), 97-111. http://dx.doi.org/10.1108/02652320010339617

Arnold, K. A., \& Bianchi, C. (2001). Relationship marketing, gender, and culture: Implications for consumer behavior. Advances in Consumer Research, 28.

Awwad, M. S. (2011). An application of the American Customer Satisfaction Index (ACSI) in the Jordanian Mobile Phone Sector. The TQM Journal, 24, 529-541. http://dx.doi.org/10.1108/17542731211270098

Ball, A. D., Coelho, P. S., \& Vilares, M. J. (2006). Service Personalization and Loyalty, 1(1). Retrieved from $\mathrm{http}: / /$ digitalcommons, unl.edu/marketingfacpu

Bennett, R., \& Rundle-Thiele, S. (2004). Customer Satisfaction should not be the only Goal. Journal of Services Marketing, 18, 514-523. http://dx.doi.org/10.1108/08876040410561848

Berry, L. L. (1983). Relationship Marketing. In L. L. Berry, L. Shostack, \& G. Upah (Eds.), Emerging Perspectives on Services Marketing. Chicago: American Marketing Association.

Berry, L. L. (1995). Relationship Marketing of Services: Growing interest, emerging perspectives. Journal of the Academy of Marketing science, 23, 236-245. http://dx.doi.org/10.1177/009207039502300402

Binninger, A. S. (2008). Exploring the Relationships between Retail Brands and Customer Store Loyalty. International Journal of Retail \& Distribution Management, 36(2), 94-110. http://dx.doi.org/10.1108/09590550810853057

Blau, P. M. (1960). A theory of social integration. The American Journal of Sociology, 65, 545-556. http://dx.doi.org/10.1086/222785

Boshoff, C. (1999). Recovosat: An instrument to measure satisfaction with transaction-specific service recovery. Journal of services research, 1, 236. http://dx.doi.org/10.1177/109467059913005

Boshoff, C., \& Leong, J. (1998). Empowerment, Attribution and Apologies as Dimensions of Service Recovery. International Journal of Service Industry Management, 9(1), 24-47. http://dx.doi.org/10.1108/09564239810199932

Caceres, R. C., \& Paparoidamis, N. G. (2007). Service Quality, Relationship Satisfaction, Trust, Commitment and Business-to-Business Loyalty. European Journal of Marketing, 41(7/8), 836-867. http://dx.doi.org/10.1108/03090560710752429

Casielles, R., Alvarez, L., \& Martin, A. (2005). Trust as a Key Factor in Successful Relationships between Consumers and Retail Service Providers. The Service Industries Journal, 25(1), 83-101. http://dx.doi.org/10.1080/0264206042000302423

Chattananon, A., \& Trimetsoontorn. (2009). Relationship marketing A Thai Case. International Journal of Emerging Markets, 4(3), 252-274. http://dx.doi.org/10.1108/17468800910968418

Chiu, H., Hsieh, Y., Li, Y., \& Lee, M. (2005). Relationship Marketing and Customer Switching Behaviour. Journal of Business Research, 58, 1682-1689. http://dx.doi.org/10.1016/j.jbusres.2004.11.005

Churchill, G. A., \& Surprenant, C. (1982). An investigation into the determinants of customer satisfaction. Journal of Marketing Research, 19(4), 491-504. http://dx.doi.org/10.2307/3151722

Claycomb, \& Martin. (2001). Building customer relationships: An inventory of service providers objectives and 
$\begin{array}{lllll}\text { practices. } \quad \text { Marketing intelligence } \quad \& \quad \text { planning, } & \text { 19(6), 385-399. }\end{array}$ http://dx.doi.org/10.1108/EUM0000000006109

Coelho, P. S., \& Henseler, J. (2012). Creating Customer Loyalty through Service Customization. European Journal of Marketing, 46, 331-356. http://dx.doi.org/10.1108/03090561211202503

Dewitt, T., Nguyen, T., \& Marshall, R. (2007). Exploring Customer Loyalty following Service Recovery: The Mediating Effects of Trust and Emotions. Journal of Service Research, 10(269), 269-281.

Ehigie, B. O. (2006). Correlates of customer loyalty to their banks: A case study in Nigeria. International Journal of Bank Marketing, 24(7), 494-508. http://dx.doi.org/10.1108/02652320610712102

Ekiz, E. H., \& Au, N. (2011). Comparing Chinese and American attitudes towards Complaining. International $\begin{array}{llll}\text { Journal of Contemporary Hospitality } & \text { Management, 20(3), 327-343. }\end{array}$ http://dx.doi.org/10.1108/09596111111122514

Ernest, I. E. (2012). Bank consolidation in Nigeria: Marketing implications and challenges for the surviving banks. Arts and Sciences Journal, 2012.

Evanschitzky, H., \& Wunderlich, M. (2006). An Examination of Moderator Effects in the Four-Stage Model. Journal of Service Research, 8, 330-345. http://dx.doi.org/10.1177/1094670506286325

Fang, T. (2003). A critique of Hofstede's Fifith national culture dimension. International Journal of Cross Cultural Management, 2003(3), 347. http://dx.doi.org/10.1177/1470595803003003006

Fayolle, A., Basso, O., \& Bouchard, V. (2010). Three levels of Culture and Firms' Entrepreneurial Orientation: A research Agenda. Entrepreneurship \& Regional Development, 22, 7-8. http://dx.doi.org/10.1080/08985620903233952

Fornell, C., Johnson, M. D., Anderson, E. W., Cha, J., \& Bryant, B. E. (1996). The American Customer Satisfaction Index: Nature, Purpose, and Findings. Journal of Marketing, 60(4), 7-18. http://dx.doi.org/10.2307/1251898

Frost, D., Goode, S., \& Hart, D. (2009). Individualist and Collectivist Factors Affecting Online Repurchase Intentions. Internet Research, 20(1), 6-28. http://dx.doi.org/10.1108/10662241011020815

Geddie, M. W., DeFranco, A. L., \& Geddie, M. F. (2005). A Comparison of Relationship Marketing and Guanxi: Its Implications for the Hospitality Industry. International Journal of Contemporary Hospitality Management, 17, 614-632. http://dx.doi.org/10.1108/09596110510620681

Gelfand, M. J., Leslie, L. M., \& Fehr, R. (2008). To prosper, Organizational psychology should adopt a global perspective. Journal of Organizational Behavior, 29, 493-517. http://dx.doi.org/10.1002/job.530

Gronroos, C. (1990a). Marketing Redefined. Management Decision, 28(8), 5-9. http://dx.doi.org/10.1108/00251749010139116

Gronroos, C. (1990b). Relationship approach to the marketing function in service contexts: The marketing and organizational behaviour interface. Journal of Business Research, 20(1), 3-12. http://dx.doi.org/10.1016/0148-2963(90)90037-E

Gronroos, C. (1994). From Marketing Mix to Relationship Marketing-Towards a Paradigm Shift in Marketing. Management Decision, 32(2), 4-20. http://dx.doi.org/10.1108/00251749410054774

Gummeson, E. (1994). Making Relationship Marketing Operational. International Journal of Service Industry Management, 5(5), 5-20. http://dx.doi.org/10.1108/09564239410074349

Gummeson, E., \& Groonroos, C. (2012). The Emergence of the New Service Marketing: Nordic School $\begin{array}{lllll}\text { Perspective. Journal of } & \text { Service }\end{array}$ http://dx.doi.org/10.1108/09564231211260387

Gurbuz, E. (2008). Retail store branding in Turkey: Its effect on perceived equity, satisfaction and loyalty. European Journal of Business, 3, 286-304. http://dx.doi.org/10.1108/14502190810906446

Gustafsson, A., Johnson, M. D., \& Roos, I. (2005). The Effects of Customer Satisfaction, Relationship Commitment Dimensions, and Triggers on Customer Retention. Journal of Marketing, 69(4), 210-218. http://dx.doi.org/10.1509/jmkg.2005.69.4.210

Halimi, A. B., Chavosh, A., \& Choshali, S. H. (2011). The Influence of Relationship Marketing Tactics on Customer's Loyalty in B2B Relationship-The Role of Communication and Personalization. European Journal of Economics, Finance and Administrative Sciences, 31, 49-56.

Hallowell, R. (1996). The Relationship of Customer Satisfaction, Customer loyalty and Profitability: An Empirical Study. International Journal of Service Industry Management, 7(4), 27-42. 
http://dx.doi.org/10.1108/09564239610129931

Hamidzadeh, M. R., Jazani, N., Hajikarimi, A., \& Ebrahimi, A. (2011). A Model of Explanation of Customer Satisfaction Consequence in Banking Industry: Evidence from Iran. International Business and Management, 3(1), 141-147.

Hassan, M. T., \& Anwar, A. (2012). Measuring Customer Loyalty of Islamic banks in Bahawalpur Region. International Journal of Learning and Development, 2(2). http://dx.doi.org/10.5296/ijld.v2i2.1593

Hau, L. N., \& Ngo, L. V. (2011). Relationship Marketing in Vietnam: An Empirical Study. Asia Pacific Journal of Marketing and Logistics, 4(2), 225-235.

Hoffmann, A. O. I., \& Bimbrich, C. (2012). The impact of fraud prevention on bank customer relationship: An empirical investigation in retail banking. International journal of bank marketing, 30, 390-407. http://dx.doi.org/10.1108/02652321211247435

Hofstede, G. (1980). Culture's Consequences: Int. Difference in Work-Related Values. Beverly Hills, CA: Sage.

Hofstede, G. (1983). The cultural relativity of organizational practices and theories. Journal of International Business Studies, 14(2), 75-89. http://dx.doi.org/10.1057/palgrave.jibs.8490867

Hofstede, G. (1991). Cultures and Organizations: A Software of the Mind. London, UK: McGraw Hill.

Hui, M. K., Ho, C. K. Y., \& Wan, L. (2011). Prior Relationships and Consumer Responses to Service Failures: A Cross-Cultural Study. Journal of International Marketing, 19(1), 59-81. http://dx.doi.org/10.1509/jimk.19.1.59

Hunt, S., Arnett, D., \& Madhavaram, S. (2006). The Explanatory Foundation of Relationship Marketing Theory. Journal of Business \& Industrial Marketing, 21(2), 72-87. http://dx.doi.org/10.1108/10610420610651296

John, J. D., John, J., \& Baker, D. (2011). Control and participation at the service encounter: A cultural value-based perspective. International Journal of Business and Social Science, 2(22), 7-14.

Johson, M. D., Gustafsson, A., Anderssen, T. W., Lervic, L., \& Cha, J. (2001). The evolution and future of national customer satisfaction index model. Journal of Economic Psychology, 22, 217-245. http://dx.doi.org/10.1016/S0167-4870(01)00030-7

Kantsperger, R., \& Kunz, W. H. (2010). Consumer Trust in Service Companies: A Multiple Mediating Analysis. Managing Service Quality, 20(1), 4-25. http://dx.doi.org/10.1108/09604521011011603

Kaynak, E., \& Harcer, T. D. (2004). American customer's attitudes towards commercial banks. International Journal of bank marketing, 23(1), 73-89. http://dx.doi.org/10.1108/02652320510577375

Kaynak, E., \& Whiteley, A. (1999). Retail bank marketing in Western Australia. International journal of Bank marketing, 17(5), 221-232. http://dx.doi.org/10.1108/02652329910292693

Kitapei, O., \& Dortyol, I. T. (2009). The Differences in Customer Complaint Behaviour between Loyal Customers and First Comers in the Retail Banking Industry: The Case of Turkish customers. Management Research News, 32, 932-941. http://dx.doi.org/10.1108/01409170910994141

Kiyani, T. M., Niazi, M. R. U. K., Rizvi, R. A., \& Khan, I. (2012). The Relationship between Brand Trust, Customer Satisfaction and Customer Loyalty: Evidence from Automobile Sector of Pakistan. Interdisciplinary Journal of Contemporary Research in Business, 4, 489-504.

KPMG. (2012). Banking Industry Customer Satisfaction Survey. Nigeria, Lagos: KPMG Professional Services.

KPMG. (2013). Banking Industry Customer Satisfaction Survey. Nigeria, Lagos: KPMG Professional Services.

Kueh, K., \& Voon, B. (2007). Culture and Service Quality Expectations: Evidence from Generation Y Consumers in Malaysia. International Journal of Service Quality, 17, 656-680. http://dx.doi.org/10.1108/09604520710834993

Kumunda, M., \& Osarenkhwe, A. (2012). Remedy or Cure for Service Failure? Effects of Service Recovery on Customer Satisfaction and Loyalty. Business Process Management Journal, 18(1), 82-103. http://dx.doi.org/10.1108/14637151211215028

Lai, J., He, P., Cho, H., \& Zhou, L. (2013). Impact of National Culture on Online Consumer Review Behavior. Global Journal of Business Research, 7(1).

Lambe, C. J., Wittman, C. M., \& Spekman, R. E. (2001). Social exchange theory and research on business-to-business relational exchange. Journal of Business-to-Business Marketing, 8(3), 1-6. http://dx.doi.org/10.1300/J033v08n03_01

Leverin, A., \& Liljander, V. (2006). Does Relationship Marketing Improve Customer Relationship Satisfaction and Loyalty? International Journal of Bank Marketing, 24(4), 232-251. 
http://dx.doi.org/10.1108/02652320610671333

Liu, C., Guo, Y. M., \& Lee, C. (2011). The Effects of Relationship Quality and Switching Barriers on Customer Loyalty. International Journal of Information Management, 31(1), 71-79. http://dx.doi.org/10.1016/j.ijinfomgt.2010.05.008

Lobato-Calleros, O., Rivera, H., Serrato, H., Gomez, E., \& Carvantes, P. (2013). The Mexican User Satisfaction Index: A Case Study applied to Social program. The TQM Journal, 25, 384-398. http://dx.doi.org/10.1108/17542731311314872

Luczak, C. O., Neill, S. M., \& Hills, G. (2010). National Culture, Market Orientation and Network Driven Benefits: Conceptual Model for Service SME's. Academy of Entrepreneurship Journal, 16(2).

McColl-Kennedy, J. R., \& Sparks, B. A. (2003). Application of Fairness Theory to Service Failures and Service Recovery. Journal of Service Research, 5(3), 251-266. http://dx.doi.org/10.1177/1094670502238918

McCollough, M. A., Berry, L. L., \& Yabad, M. S. (2000). An Empirical Investigation of Customer satisfaction after Service failure and Recovery. Journal of Service Research, 3, 121. http://dx.doi.org/10.1177/109467050032002

Mende, M., Bolton, N. R., \& Bitner, M. J. (2013). Decoding Customer-Firm Relationships: How attachment Styles Help Explain Customers' Preferences for Closeness, Repurchase Intentions and Changes in Relationship Breadth. Journal of Marketing Research, 1, 125-142. http://dx.doi.org/10.1509/jmr.10.0072

Molina, A., Martin-Consuegra, D., \& Esteben, A. (2007). Relational Benefits and Customer Satisfaction in Retail Banking. International Journal of Business Marketing, 25(4), 253-271. http://dx.doi.org/10.1108/02652320710754033

Morgan, R. M., \& Hunt, S. D. (1994). The Commitment-Trust Theory of Relationship Marketing. Journal of Marketing, 58, 20-38. http://dx.doi.org/10.2307/1252308

Moshirian, F. (2012). The future and dynamics of global systemically important banks. Journal of Banking and Finance, 36, 2675-2679. http://dx.doi.org/10.1016/j.jbankfin.2012.04.008

Naoui, F. B., \& Zaiem, I. (2012). The Impact of Relationship quality on Client's loyalty: An Application in the Para-pharmaceutical Industry. International Journal of Pharmaceutical and Healthcare Marketing, 4(2), 137-156. http://dx.doi.org/10.1108/17506121011059759

Narteh, B., Agbemabiese, G. C., Kodua, P., \& Braimah, M. (2013). Relationship marketing and customer loyalty: Evidence from the Ghanaian Luxury Hotel Industry, 22, 407-436.

Ndubisi, N. O., \& Wah, C. K. (2005). Factional Discriminant Analysis of the Underpinnings of Relationship Marketing and Customer Satisfaction. International Journal of Bank Marketing, 23, 542-557. http://dx.doi.org/10.1108/02652320510629908

Ndubisi, N. O., Khoo-Lattimore, C., Yang, L., \& Capel, C. M. (2011). The Antecedents of Relationship Quality in Malaysia and New Zealand. International Journal of Quality and Reliability Management, 28(2), 233-248. http://dx.doi.org/10.1108/02656711111101773

Ndubisi, N. O., Wah, C. K., \& Ndubisi, G. C. (2007). Supplier-Customer Relationship Management and Customer Loyalty: The Banking Industry Perspective. Journal of Enterprise Information Management, 20(2), 222-236. http://dx.doi.org/10.1108/17410390710725797

Newman, K. I., \& Nollen, S. D. (1996). Cultural and congruence: The fit between management practice and national culture. Journal of international business studies, 27(4), 75-79. http://dx.doi.org/10.1057/palgrave.jibs.8490152

Nunnally, J. C. (1978). Psychometric theory (2nd ed.). Newyork: McGraw Hill.

Ogbadu, E. E., \& Usman, A. (2012). Imperatives of Customer Relationship Management in Nigerian Banking Industry. Kuwait Chapter of Arabian Journal of Business and Management Review, 2(1), 59-73.

Oke, B. A. (1994). Regulations of Banks and other Financial Institutions with Special Reference to the Regulation of Discount Houses in Nigeria, Central Bank of Nigeria. Economic and Financial Review, 29(10), 1-6.

Oliver, R. L. (1980). A cognitive model of the antecedents and consequences of satisfaction decisions. Journal of Marketing Research, 17, 460-469. http://dx.doi.org/10.2307/3150499

Oliver, R. L. (1997). Satisfaction: A Behavioural Perspective on the Consumer. New York, NY: McGraw-Hill.

Oliver, R. L. (1999). Whence Customer Loyalty? Journal of Marketing, 63, 33-44. http://dx.doi.org/10.2307/1252099 
Ooi, K. B., Lin, B., Tan, B. I., \& Chong, A. Y. (2011). Are TQM Practices Supporting Customer Satisfaction and $\begin{array}{lllll}\text { Service } \quad \text { Quality? Journal of } & \text { Services }\end{array}$ http://dx.doi.org/10.1108/08876041111161005

Opportunities for Innovation in the Delivery of Interactive Retail Services. (n. d.). Journal of Interactive Marketing, 24, 155-167.

Orsingher, C., Valentine, S., \& Agnes, M. D. (2010). A meta-analysis of satisfaction with Complaint handling in services. Journal of the Academy of Marketing, 38,169-186. http://dx.doi.org/10.1007/s11747-009-0155-z

Palmatier, R. W., Javis, C. B., Bechkoff, J. R., \& Kardes, F. R. (2009). The Role of Customer Gratitude in Relationship Marketing. Journal of Marketing, 73(5), 1-8. http://dx.doi.org/10.1509/jmkg.73.5.1

Papasolomou, I., \& Vrontis, D. (2006). Building corporate branding through internal marketing: The case of the UK retail bank industry. Journal of product \& brand management, 15(1), 37-47. http://dx.doi.org/10.1108/10610420610650864

Patterson, P. G., Cowley, E., \& Prasongsukam. (2006). Service Failure Recovery: The Moderating Impact of Individual-level Cultural Value Orientation on Perceptions of Justice. International Journal of Research in Marketing, 23, 263-277. http://dx.doi.org/10.1016/j.jiresmar.2006.02.004

Riel, A. C. R., Liljander, V., Semeijn, F., \& Polsa, P. (2011). EU deregulation and dealer-supplier relations in automotive distribution. Journal of Business \& Industrial Marketing, 26(2), 115-131. http://dx.doi.org/10.1108/08858621111112294

Robbinson, C., Abbott, J., \& Shoemaker, S. (2005). Recreating cheers: An analysis of relationship marketing as an effective marketing technique for quick-service restaurants. International Journal of Contemporary Hospitability Management, 17(7), 590-599. http://dx.doi.org/10.1108/09596110510620663

Rutti, R. M., Helms, M. M., \& Rose, L. C. (2012). Changing the lens: Viewing the mentoring relationship as relational structures in a social exchange framework. Leadership \& Organization Development Journal, 34, 446-468. http://dx.doi.org/10.1108/LODJ-11-0097

Santonen, T. (2007). Price sensitivity as an indicator of customer defection in retail banking. International Journal of Bank Marketing, 25(1), 39-55. http://dx.doi.org/10.1108/02652320710722605

Sin, I., Tse, A., \& Yim, F. (2005a). CRM: Conceptualization and scale development. European Journal of Marketing, 39, 1264-1290. http://dx.doi.org/10.1108/03090560510623253

Sin, L. Y. M., Tse, A. C. B., Yau, O. H. M., Chow, R. P. M., Lee, J. S. Y., \& Lu, L. B. Y. (2005b). Relationship Marketing Orientation: Scale Development and Cross-Cultural Validation. Journal of Business Research, 58(2), 185-194. http://dx.doi.org/10.1016/S0148-2963(02)00493-9

Singh, J. (1998). Customer complaint intentions and behaviour: Definitional and taxonomical issues. Journal of Marketing, 52, 193-207.

Soludo, C. (2006). Beyond Banking Sector Consolidation in Nigeria. Presentation at Global Banking Conference on Nigerian Banking Reforms, 29th March, 2006, Dorchester Hotel, London.

Thibaut, J. W., \& Kelley, H. H. (1959). The social psychology of groups. New York: John Wiley \& Sons Inc.

Vaerenbergh, Y. V., Lariviere, B., \& Vermier, I. (2012). The Impact of Process Recovery Communication on Customer Satisfaction, Repurchase Intention and Word-of-Mouth Intentions. Journal of Service Research, 15, 262. http://dx.doi.org/10.1177/1094670512442786

Webster, C., \& Sundaram, D. S. (1998). Service Consumption Criticality in Failure Recovery. Journal of Business Research, 41(2), 153-159. http://dx.doi.org/10.1016/S0148-2963(97)00004-0

Winsted, K. F. (1997). The Service Experience in Two Cultures: A Behavioural Perspective. Journal of Retailing, 77, 337-360. http://dx.doi.org/10.1016/S0022-4359(97)90022-1

Zeithaml, V. A., Berry, L. L., \& Parasuraman, A. (1996). The Behavioural Consequences of Service Quality. Journal of Marketing, 60(2), 31-46. http://dx.doi.org/10.2307/1251929

\section{Copyrights}

Copyright for this article is retained by the author(s), with first publication rights granted to the journal.

This is an open-access article distributed under the terms and conditions of the Creative Commons Attribution license (http://creativecommons.org/licenses/by/3.0/). 